E3 Journal of Environmental Research and Management Vol. 7(2). pp. 0038-0044, July, 2016

Available online http://www.e3journals.org

ISSN 2141-7466 @ E3 Journals 2016

DOI : http://dx.doi.org/10.18685/EJERM(7)2_EJERM-16-018

\title{
Impact of human activities on land degradation IN Lugari sub- county, Kakamega county, Kenya
}

\author{
Wanyonyi Raphael Wanjala $^{1^{*}}$ and Mwangi James Kinyanjui ${ }^{2}$ \\ ${ }^{1}$ Tangaza University College Nairobi Kenya ${ }^{2}$ Karatina University Karatina Kenya
}

Accepted 27 October, 2016

This study investigated the impact of human activities on land degradation in Lugari Sub-County, Kakamega County in Kenya. The study sought to analyze the extent of land degradation; identify the causative factors for land degradation and analyze the effect of implemented land conservation measures and propose sustainable land use options in Lugari Sub-County. The study used four Landsat satellite images; A Multi Spectral Scanner (MSS) of 1973, Landsat Thematic Mapper, TM of 1988, Enhanced Thematic Mapper, ETM of 2003 and Enhanced Thematic Mapper Plus, ETM+ of 2010 to develop time series land use and land use change maps of Lugari SubCounty. Data was confirmed by historical data and ongoing human activities from a socio economic survey and secondary sources. Soil erosion, soil fertility loss and pollution of the environment were associated with land use change. Correlations and regression were used to identify the human activities that have significant contribution to land cover change. Findings revealed that poor cultivation methods and traditional livestock grazing methods are the major factors contributing to land degradation. The study proposes the adoption of modern agricultural technologies to meet the nutritional, developmental and energy demands of the rural communities and ensures sustainable productivity of the land.

Key Words: Land Degradation, Land Use, Land Cover Change

\section{INTRODUCTION}

Environmental degradation is a result of the interplay between socio-economic, institutional and technological forces (Githiomi and Oduor, 2012). The rapid industrial development of recent years has led to a number of shared environmental problems in the world. These include diminishing forests, altered or lost habitats and loss of biodiversity (Knowler and Bradshaw, 2007) severe land degradation, polluted water and declining availability of clean water and the degradation of marine and coastal resources (Gedikoglu and McCann, 2012).

Nkonya et al (2011) identified biophysical and unsustainable land management practices as the immediate causes of land degradation. They listed population density, poverty, land tenure, and access to agricultural extension, infrastructure, and markets, as well as policies that promote the use of land degrading practices as the underlying causes of land degradation.

\footnotetext{
${ }^{*}$ Corresponding authors: E-mail: ralphcfx@gmail.com
}

Population impacts on the environment primarily through over utilization and mismanagement of natural resources and production of wastes that are directly associated with environmental stress (Matano et al., 2015) which leads to loss of biodiversity, air and water pollution.

In most parts of the world, land degradation occurs due to human activities and natural factors. According to Ademiluyi et al (2008), Africa has among the fastest rates of deforestation in the world associated with competing land uses which are mainly agriculture and human settlements. The rising demand for fuel wood and charcoal is also a major cause of deforestation and land degradation in this region where biomass is the main source of energy for domestic uses. (Matano et al., 2015) The high population growth rates and migration in response to shortage of land resources are important factors contributing to the degradation of agricultural land (Diagana, 2003).

Maitima et al (2004) explained that soil erosion is a common phenomenon in the intensively grazed areas of sub Saharan Africa due to lack of pasture management 
practices. Here, expansion of livestock farming practices, the increase in their numbers and in some places integration with rain fed agriculture in low potential areas leads to soil erosion. Land degradation by depletion of soil nutrients is widespread in areas of subsistence farming especially as a result of removal of crop residue from farmlands either by burning or for domestic energy. This type of degradation intensifies the acidity levels in the soils and may trigger soil erosion, and also reduces crop yields (FAO, 2001).

Management and utilization of natural resources is often considered as the most critical environmental problem in Kenya. However, pollution from industrial and domestic sources and related public health problems is also becoming a real menace. Water and air pollution and domestic and industrial wastes are some of the critical diseconomies that have resulted from the process of industrial expansion and social transformation in the country (Kamau, 2010).

Land degradation impacts directly and indirectly on people's livelihoods, their vulnerability and food security (McDonagh et al, 2006). Bationo et al (2006) stated that land degradation is the most serious threat to food production, food security, and natural resource conservation in Africa. They explained that the African population is trapped in a vicious cycle between land degradation and poverty, and the lack of resources and knowledge to generate adequate income and opportunities to overcome the challenges of land degradation.

Due to land degradation, Net Primary Productivity (NPP) index decreased in South Africa with a 41 per cent reduction in croplands (Bai and Dent 2007) About 17 million people, $38 \%$ of the South African population, depend on these degrading areas. Using GIS analysis, Kayhko et al (2010) demonstrated effects of land degradation on forest resources in Zanzibar, Tanzania. They reported that about 6 million hectares of primary forest is lost annually due to agriculture, logging, and other human activities responsible for land use and land cover changes (FAO, 2006; Lambin et al, 2003). In Kenya over the period 1981-2003, NPP increased in woodland and grassland, but hardly at all in cropland and in $40 \%$ of cropland it decreased. This was in the context of a doubling of human population over the same period and an increased demand for food resources (Bai and Dent 2006).

In Sub-Saharan Africa, most economic developments are agriculturally based with two thirds of African countries depending on agriculture for their livelihoods. Diagana (2003) explains that in this region, most farmers are small holders with 0.5 to 2 ha of land and who earn less than US $\$ 1$ a day. Many of the farmers face 3-5 months of hunger, have large families and are malnourished. The fate of the agricultural sector, therefore, directly affects economic growth, poverty eradication programs and the social welfare of livelihood in Africa. In Kenya specifically, agricultural productivity and food security are currently under serious threat due to the decline in soil fertility (Kabubo-Mariara, Linderhof, Kruseman, Atieno and Mwabu, 2010).

Land use changes in Kenya and East Africa have transformed land cover to farmlands, grazing lands, human settlements, and urban centres at the expense of the natural vegetation (Kabubo-Mariara et al., 2010). These changes are associated with deforestation, biodiversity loss, and land degradation (Maitima et al, 2009). For example, in the early 2000 s, approximately 30 $\%$ of Kenya's land was affected by very severe to severe land degradation and an estimated 12 million people, equivalent to a third of the Kenya's population, depended directly on that land which was being degraded (Bai and Dent, 2008).

Improving agricultural productivity is central in achieving Kenya's Vision 2030 goals. However, widespread land degradation, exemplified by soil erosion and declining soil fertility, which in turn leads to falling production, remains a big challenge in the region (Kimaru and Jama, 2005). Over the last three decades, soil erosion and land degradation have become major environmental concerns and present a formidable threat to food security and sustainability of agricultural production (Kabubo-Mariara et al., 2010).

In Lugari Sub-County deforestation is still rampant particularly in villages and among farmers where land for cultivation is priority. Population pressure, improper Government policies and disruption of indigenous traditional land-use management practices, have contributed to accelerated degradation of forest land and loss of biodiversity (Wafuke, 2012). These human activities have resulted in intensive land use, modification, and alteration of the status of the land use and land cover change over time as stated in the Lugari Sub-County Development Plan, 2008-2012. This study therefore sought to;

Analyse the extent of land degradation in Lugari SubCounty

Identify the causative factors for land degradation in Lugari Sub-County

Analyze the effect of implemented land conservation measures and propose sustainable land use options.

\section{METHODOLOGY}

Lugari Sub-County in Kakamega County Kenya occupies 670.2 sq. $\mathrm{km}$ equivalent to $0.12 \%$ of the total area of Kenya. The Sub-County lies at the altitude of $1300-1800$ Metres above sea level, between longitudes $34^{\circ} 28^{\prime}$ and $35^{\circ}$ East and between latitude $0^{\circ} 25^{\prime}$ and $1^{0}$ North of the equator.

In the 2009 housing and population census, the SubCounty had a population of 292,151 people with an annual growth rate of $4.1 \%$, one of the highest in the 
country. The high population increase will definitely have negative impacts on the development of the Sub-County as well the pressure on land and natural resources available in the Sub-County. Agriculture is one of the main economic activities carried out in Lugari SubCounty, specifically livestock rearing and cultivation.

The study used four Landsat satellite images; A Multi Spectral Scanner (MSS) of 1973, Landsat Thematic Mapper, TM of 1988, Enhanced Thematic Mapper, ETM of 2003 and Enhanced Thematic Mapper Plus, ETM+ of 2010 to develop time series land use and land use change maps of Lugari Sub-County. The Landsat Thematic Mapper (TM) imagery provides seven Multi Spectral channels (3 visible, 1 near-infrared, 2 midinfrared, 1 thermal-infrared) at 30-meter resolution (120meter resolution for the thermal-infrared band). Enhanced Thematic Mapper Plus (ETM+) adds an extra 15-meter resolution panchromatic band and improved resolution for the thermal-infrared band (60-meters).

ERDAS imagine remote sensing software and ArcGIS 10.2 were used for the image geo-referencing and land cover processing. Various color composites and band ratios were derived to enable image interpretation. In false colour composites of bands 4, 3, 2 which offers information and color contrasts enabling the classification. This captured details relating to natural forests, planted forests, farmlands, cleared forests, sugarcane zones, shrubs and riverine vegetation.

The image classification process involved both supervised and unsupervised classification in order to come up with a current depiction of the state of land use and land cover in the Sub-County. Six thematic vegetation types i.e. forest plantation, cleared forests, agricultural farmlands, sugarcane zone, riverine vegetation, and shrub lands were digitized as training sites for the supervised classification. This was followed by on screen digitization to clarify different land use clusters since the study area is small and details of land use could be confirmed from other sources such as the Google earth maps. The same procedure was repeated for all the years of monitoring. The vector layers were used to derive areas of land use change over time in Arc GIS software and such areas were identified for patterns to allow attribution of the causes of change.

To confirm the cause of land cover change and identify the impacts on the ground, a survey using a set of questionnaires in 100 sampled households was used to test land use activities, household composition, and income/source of livelihood, education, and land management and conservation measures at household levels. The sampling was proportionally allocated to cover the two agro-ecological zones; Upper Midland (UM3/UM4) s and Lower Midland (LM2 LM3-4) zones of the study area (Kenya Soil Survey [KSS], 2011).

Sampling was also done to identify the key informants from government departments like the KFS (Kenya Forest Service), KEFRI (Kenya Forestry Research Institute), District Agricultural Officer(DAO), DELDO (District Environment and Land Development Officer), and National Environment Management Authority (NEMA). The study also employed field observation and photo recording techniques to gather and capture information on indicators of land degradation. Field survey also provided opportunities to the researcher to gather and review the available existing secondary data and documentations from Kakamega County Offices.

The data collected were first collated, and then assigned to numerical codes. Both questionnaires were designed to allow the vital statistics on the responses be sought, and included variables such as sex, household composition, occupation and educational level of the household members, land ownership, and land management practices. Correlation and regression analysis were performed. The regression equation is shown below.

\section{Independent variables (Land use)}

Cultivation $\left(X_{1}\right)$, construction $\left(X_{2}\right)$, grazing $\left(X_{3}\right)$, fallow land $\left(X_{4}\right)$, agro forestry $\left(X_{5}\right)$, forest plantation $\left(X_{6}\right)$

Dependent Variable

Land Degradation ( $\mathrm{Y}$ )

The multiple regression model is thus represented as;

$Y=a+\beta_{1} X_{1}+\beta_{2} X_{2}+\beta_{3} X_{3}+\beta_{4} X_{4}+\beta_{5} X_{5}+\beta_{6} X_{6}$

The $\beta$-values tell us about the relationship between land degradation and each predictor variable (land use and land management practices).

The collected data were analyzed using the Statistical Package for Social Scientists (SPSS) version 18. Variables such as sex, land ownership, land use among others were analyzed using descriptive statistics such as cross tabulations and frequencies. Relationship strength using Linear Regression and Pearson's Moment Correlations were conducted (confidence level of 95\%) to test the relationship between human activities and land use land cover change (which were used as proxies of land degradation).

The study carried out a correlation to investigate the association between different land use practices responsible for land conversion and the existing land conservation measures. In this case, correlations was used to give the numerical value of the strength of this association by Land Use Land Cover Change on land degradation. The study also undertook a regression analysis of the linkage between Land Use Land Cover Change (LULCC) and land degradation so as to determine the influence of the independent variables on the dependent variable. Regression analysis allows us to be able to make predictions of relationships between variables.

\section{RESULTS}

The results show that agricultural land gradually increased throughout the study period. For instance, the area of land under rainfed agriculture increased from about 45, 836 ha to 46, 124 ha between 1973 and 1988 . This was a percentage change of 0.63 in a period of 15 
Table 1: Land use/ cover change for Lugari district between 1973 and 2010

\begin{tabular}{ccccc}
\hline Land Use & Area (Ha) 1973 & Area (Ha) 1988 & Area (Ha) 2003 & Area (Ha) 2010 \\
\hline Forest Plantation & 6736.1340 & 6841.0110 & 6223.8730 & 4785.4440 \\
Open forest & 4079.4790 & 3749.9640 & 3593.8730 & 4671.2300 \\
Rainfed agriculture & 45836.9280 & 46124.4620 & 46002.9100 & 46423.4500 \\
Riverine vegetation & 2129.1820 & 2010.6750 & 1810.3720 & 1210.6250 \\
Scrubland & 2277.3720 & 2079.7410 & 1819.5510 & 1659.6800 \\
Sugarcane plantation & 5690.5480 & 5993.7910 & 7399.1540 & 7999.2040 \\
Wetland & 261.2460 & 211.2450 & 161.1560 & 121.2560 \\
\hline Total & 67010.8890 & 67010.8890 & 67010.8890 & 67010.8890 \\
\hline
\end{tabular}

Table 2: Correlation Matrix between Land Use Land Cover Change and Land Degradation in Lugari Sub-County

\begin{tabular}{|c|c|c|c|c|c|c|c|}
\hline & Land Size & Cultivation & Construction & Grazing & $\begin{array}{c}\text { Agro- } \\
\text { Forestry }\end{array}$ & $\begin{array}{l}\text { Fallow } \\
\text { Land }\end{array}$ & $\begin{array}{c}\text { Forest } \\
\text { Plantation }\end{array}$ \\
\hline Land Size & 1 & & & & & & \\
\hline Cultivation & $-.370^{\star *}$ & 1 & & & & & \\
\hline Construction & -.167 & 0.228 & 1 & & & & \\
\hline Grazing & $-.354^{* *}$ & 0.333 & .129 & 1 & & & \\
\hline Agro forestry & $-.300^{\star *}$ & 0.137 & .105 & $.213^{*}$ & 1 & & \\
\hline Fallow land & -.037 & 0.048 & .037 & .035 & -.122 & 1 & \\
\hline $\begin{array}{l}\text { Forest } \\
\text { Plantation }\end{array}$ & -.190 & 0.100 & -.088 & .058 & $.335^{\star \star}$ & -.089 & 1 \\
\hline
\end{tabular}

* Correlation is significant at the 0.05 level (2-tailed).

** Correlation is significant at the 0.01 level (2-tailed).

years. In the next study period 2003 and 2010, the area of land under rainfed agriculture changed slightly from 46,002 ha to 46,423 ha. This period recorded a percentage increase of 0.9 in only seven years. In comparison, the population density was 206, 321, and 440 persons per square kilometer in 1989, 1999, and 2009 respectively showing a much bigger increase. The large population increase and the low increase in agricultural area was attributed a $s$ a factor leading to intensive farming which depletes soils nutrients and interferes with soil texture hence exposing it to erosion.

An analysis of the relationship between land use and land degradation is illustrated in Table 1. The output shows that land cultivation and land size have a Pearson correlation coefficient of $r=-0.370$ at significance level of $p<0.01$. This then signifies that the impact of degradation due to cultivation on the land in the area would reduce by $37 \%$ if the land size under cultivation is increased.

The output also shows a negative relationship between grazing and land size with a Pearson correlation coefficient of $r=0.354$ and the relationship is significant at 0.01 level of confidence. This level of significance indicates that the impact of degradation due to grazing activities on the land will reduce as land size increases. The correlation output also gives a negative relationship between agro forestry and land size with a Pearson correlation coefficient of $r=0.300$, which is a significant relationship with a confidence level of 0.01 .

Further, agro forestry is positively correlated to grazing with a Pearson correlation coefficient of $r=0.213$ and it is significant at $p<0.05$ confidence level. A positive relationship between agro forestry and grazing indicates that adopting agro forestry as a land conservation and management measure in the area would make it possible to increase the land for grazing of animals because intensified cultivation would definitely reduce. Lastly, the output indicates a positive, significant, linear relationship between forest plantation and agro forestry practices in the area with a Pearson correlation coefficient of $r=$ 0.335 at $p<0.01$ level of confidence. This positive relationship between the two variables would signify that the households in Lugari Sub-County engaged in forest plantation or on-farm tree planting are more likely to adopt agro-forestry practices as additional methods of land conservation and management and vice versa.

Table 2 summarizes the results of the regression analysis between land use and land degradation. From the table, a negative relationship has been generated for the model with Land degradation as the independent variable and Land use activities and management as the predictor variables for the model. Only livestock grazing and land cultivation show a significant relationship. Regression analysis assumes that the relationship 
Table 3: A summary of regression analysis between land use and land degradation

\begin{tabular}{llllllll}
\hline & \multicolumn{2}{l}{$\begin{array}{l}\text { Unstandardized } \\
\text { Coefficients }\end{array}$} & $\begin{array}{l}\text { Standardized } \\
\text { Coefficients }\end{array}$ & T & Sig. & \multicolumn{2}{c}{$\begin{array}{l}\text { 95\% Confidence } \\
\text { Interval for B }\end{array}$} \\
\hline Model & B & $\begin{array}{l}\text { Std. } \\
\text { Error }\end{array}$ & Beta & & & Lower & Upper \\
& & & & & & & \\
Bound & Bound \\
\hline (Constant) & 6.027 & 1.143 & & -272 & 0.000 & 3.755 & 8.299 \\
Cultivation & 0.890 & 0.368 & -0.242 & -2.417 & 0.018 & -1.622 & -0.158 \\
Construction & 0.438 & 0.468 & -0.093 & -0.935 & 0.352 & -1.368 & 0.493 \\
Grazing & 0.359 & 0.175 & -0.207 & -2.047 & 0.044 & -0.707 & -0.010 \\
Fallow land & 0.060 & 0.430 & -0.015 & -0.140 & 0.889 & -0.916 & 0.795 \\
Agro forestry & 0.368 & 0.192 & -0.198 & -1.917 & 0.059 & -0.750 & 0.014 \\
Forest plantation & 0.225 & 0.234 & -0.100 & -0.963 & 0.338 & -0.691 & 0.240 \\
\hline
\end{tabular}

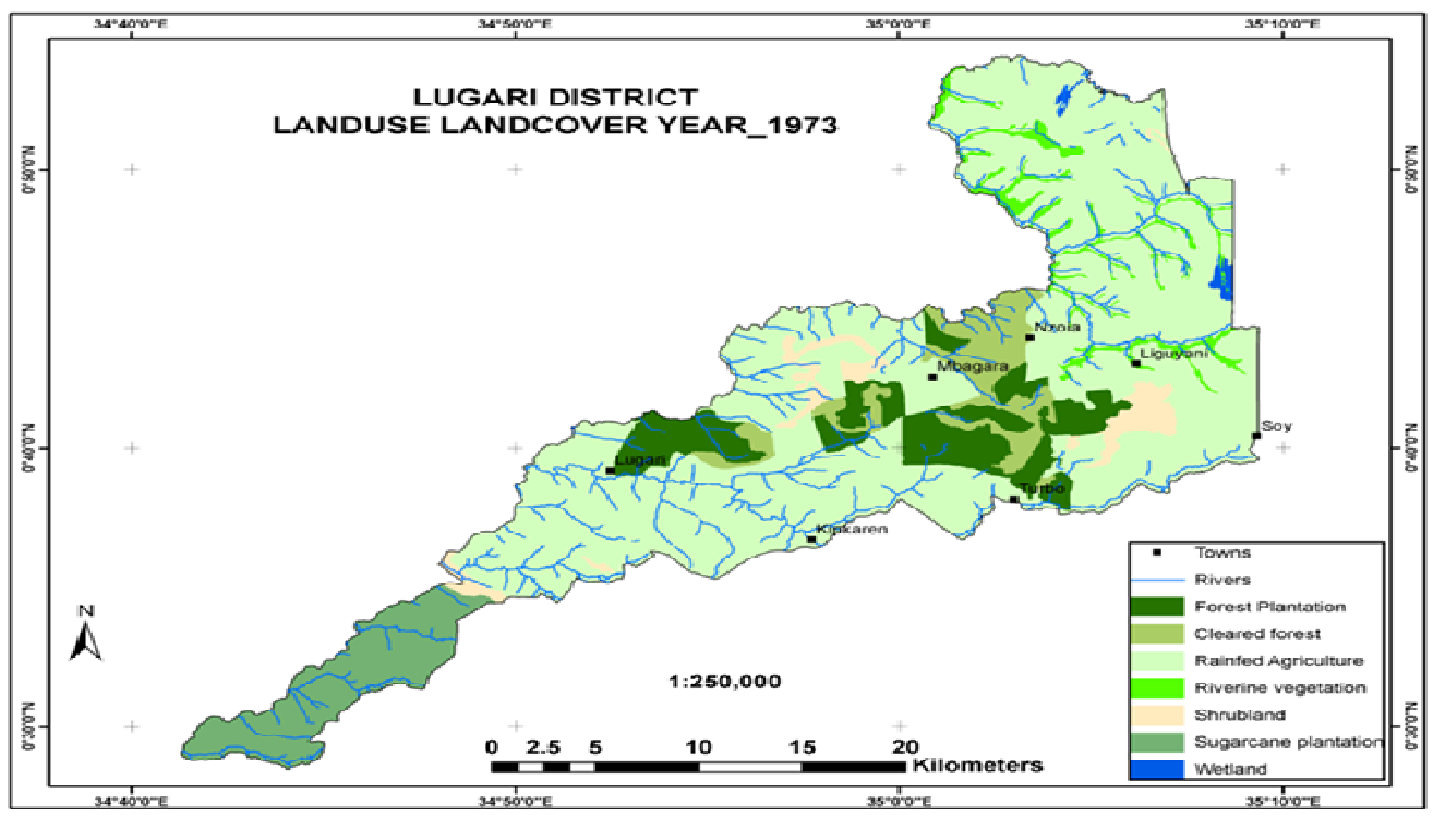

Figure 1: Lugari District Land Use Cover 1973

between variables is linear. It is a statistical procedure that measures the relative impact of each independent variable on the dependent and is useful in forecasting. The multiple regression formula that best describes the relationship between the variables is; Cultivation $(\beta=$ 0.890). This value indicates a positive relationship between land degradation and cultivation as a predictor variable. Therefore, this implies if the size of land under cultivation increases, land degradation will increase. Similarly, an increase in livestock grazing in Lugari SubCounty forest cover increases, land degradation will increase by 0.359 .

The lesser values of confidence level $(p \leq 0.05)$ from the table output of linear regression, i.e., cultivation $(p \leq$ $.018)$ and grazing $(p \leq .014)$ indicate that the sample results correspond to the research hypothesis, high population density and increased human activities in
Lugari Sub-County are significantly related to land degradation, and therefore the hypothesis is accepted.

From the regression results, the t-test associated with the $\beta$ - values for land cultivation and livestock grazing are significant because both have values that are less than 0.05 level of significance. This therefore means that land cultivation and grazing of livestock in Lugari Sub-County (two major land use forms) as predictor variables are making a significant contribution to land degradation. From the model, cultivation, [t $(-2.417)=.018, \mathrm{p}<.05$ ] and livestock grazing $[\mathrm{t}(-2.047)=.044, \mathrm{p}<.05]$. From the magnitude of the t- statistics, we can see that both cultivation and grazing have a similar impact on the land in the area of study.

Lugari Sub-County has experienced significant changes in land use and forest cover reduction between 1973 and 2010 Figure 1 and 2 emanating from a rising 


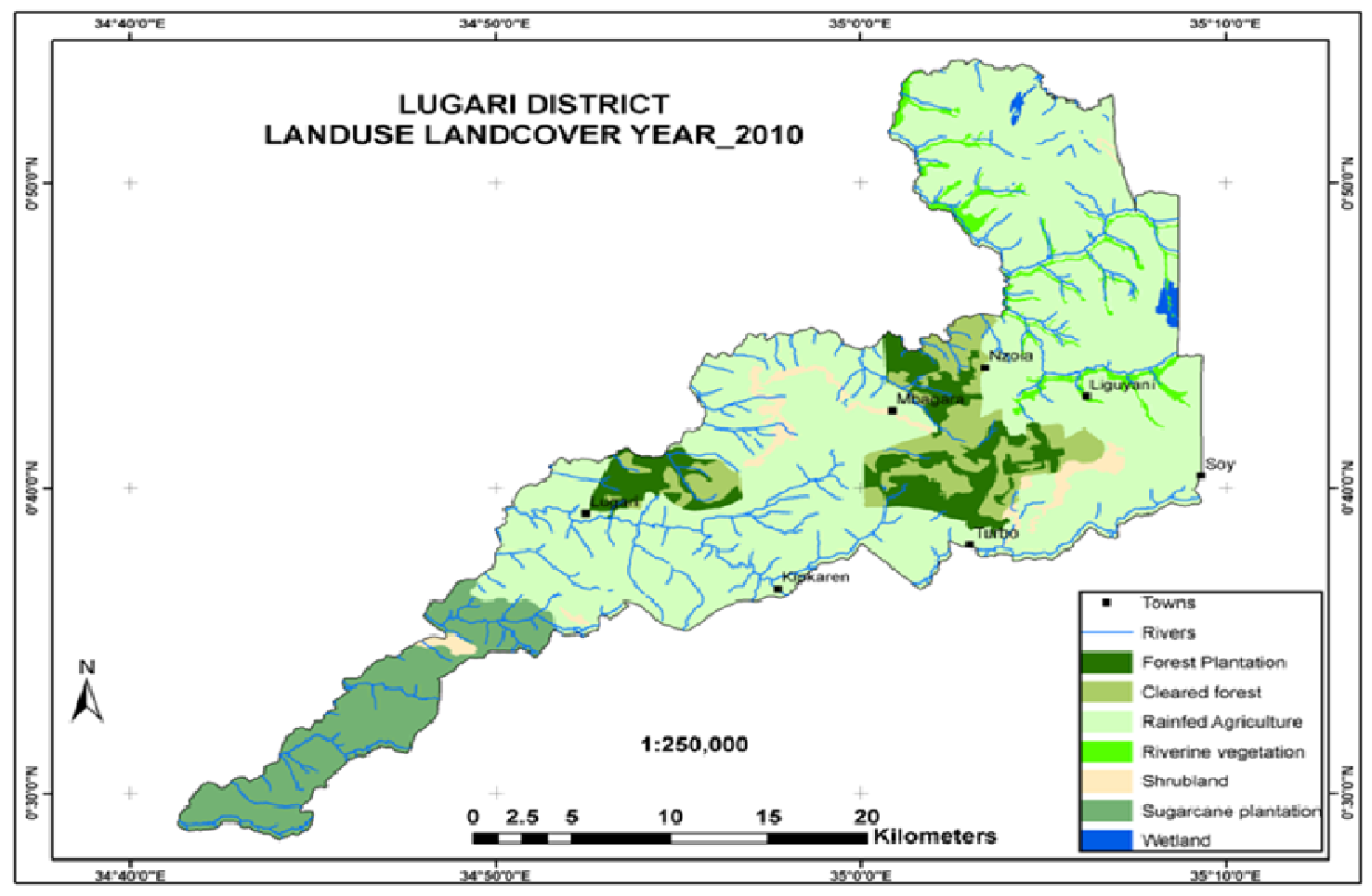

Figure 2: Lugari District Land Use Cover 2010

human population thus causing land degradation. The greatest changes occurred between 2003 and 2010 in most parts of the district. The major cause of the changes in land use and forest cover was human activities which saw the following changes take place: between 1973 and 1988 the area of land under forest plantation slightly increased by $1.56 \%$, open forest increased by about $8.1 \%$, rain fed agriculture increased by $0.63 \%$, riverine vegetation reduced by $5.57 \%$, shrub lands land reduced by $8.68 \%$, sugarcane plantation increased by $5.33 \%$, and wetlands reduced by $19.14 \%$. The period between 2003 and 2010 registered the following significant changes in only seven years: forest plantation reduced by $23.11 \%$, open forest increased by $29.98 \%$, rain fed agriculture increased by $0.91 \%$, riverine vegetation reduced by $33.13 \%$, shrub land reduced by $8.79 \%$, sugarcane plantation increased by $10.00 \%$, and wetlands reduced by $24.76 \%$.

Land cultivation and livestock grazing are the major contributing factors to land degradation in the district. At confidence level of $95 \%$ or $\mathrm{P} \leq 0.05$ both cultivation and livestock grazing had significant values as follows: cultivation $(P=.018)$ and livestock grazing $(P=.04)$. The area has also experienced a rapid growth in population density over time. For instance, population density was 206, 321, and 440 persons per square kilometer in 1989, 1999, and 2009 respectively. The growing trends of population and the consequent demand for food, energy, and housing in the area have considerably altered land use practices, reduced both plantation and natural land covers and severely caused land.

\section{DISCUSSIONS}

The results showed that there was a percentage change of 0.63 in a period of 15 years of 1973-1988 and a percentage increase of 0.9 in only seven years from 2003-2010. This has been attribute to a rapid growth in population density over time. The growing trends of population and the consequent demand for food, energy, and housing in the area have considerably altered land use practices, reduced both plantation and natural land covers and severely caused land degradation.

The study concludes that land cultivation and livestock grazing are the major contributing factors to land degradation in Lugari Sub-County. The study concludes that human clearing forest land for cultivation and grazing can be attributed to the land degradation experienced in Lugari Sub-County which has led to large rates of encroachment into forested areas.

Afforestation, reforestation, and social forestry programs should be implemented at the local levels in the area so as protect land cover and to preserve the existing forests and vegetation in the area. The government must demonstrate the benefits of agro-forestry to the farmers 
so they can participate effectively throughout the entire district to assist in reducing the pressure on available land and vegetation resources in the Sub-County.

There is need to carry out the animal/livestock carrying capacity studies and discourage the residents in this area from rearing of livestock in excess of the carrying capacity. This would introduce better producing animals in zero grazing units while farming should aim at the most adaptable and high producing cultivars of the various crops planted here. Efforts should be made to educate the residents in Lugari Sub-County and their local leaders about the adverse effects of human population on the environment through specially designed Information, Education and Communication activities.

\section{REFERENCES}

Bai ZG, Dent DL (2006). Global Assessment of Land Degradation and Improvement, Pilot Study in Kenya. Report 2006/01, FAO/ISRIC Rome/Wageningen

Bai ZG, Dent DL (2007). Land Degradation and Improvement in Argentina1: Identification by Remote Sensing. Report 2007/05, ISRIC-World Soil Information, Wageningen, Netherlands

Bai ZG, Dent DL (2008). Land degradation and improvement in South Africa: Identification by remote sensing. Report 2007/03, ISRIC World Soil Information, Wageningen, Netherlands

Bationo A, Hartermink A, Lungu O, Naimi M, Okoth P, Smaling E, Thiombiano L (2006). African Soils: Their Productivity and Profitability of Fertilizer Use. Background Paper Prepared for the African Fertilizer Summit, Abuja, Nigeria, June 2006.

Diagana B (2003). Land Degradation in Sub-Saharan Africa: Draft Working Paper, Department of Agricultural Economics and Economics, Montana State University, Bozeman, MT, USA.

Gachene CKK, Kimaru G (eds.) (2003). Soil fertility and land productivity. A guide for extension workers in the Eastern Africa region. RELMA Technical Handbook Series no. 30. Regional Land Management Unit (RELMA), Swedish International Development Agency (SIDA). Nairobi, Kenya.

Gedikoglu HL McCann (2012). Adoption of Win-win, Environment-oriented and Profit oriented Practices. Journal of Soil and Water Conservation. 67 (3), 218-227.

Githiomi JK, Oduor N (2012). Strategies for Sustainable Wood fuel Production in Kenya, International J App. Sci and Tech, 2 (10), 21-25

Hoffman MT, Todd S (2000). National review of land degradation in South Africa: the influence of biophysical and socio-economic factors. J Southern Afric stud, 26, 743-758

IUSS, (2008). Moving ahead from assessments to actions, International Conference on Land Degradation and Desertification. Mediterranean Agronomic Institute, Valenzano, Bari, Italy, September 2008

Kabubo MJ, Linderhof V, Kruseman G, Atieno R, Mwabu G (2010). Poverty-environmental links: The impact of soil and water conservation and tenure security on household welfare in Kenya, Journal of Development and Agricultural Economics, 2 (1), 041-053

Kamau EC (2010). Pollution Control in Developing Countries with a Case Study on Kenya. A Need for Consistent and Stable Regimes, Revista Internacional de Direito e Cidadania, 9, 29-42

Kenya Soil Survey. (2011). Soils of Lugari District, National Agricultural Research Laboratories, KARI.Nairobi Kenya

Kimaru G, Jama B (2005). Improving land management in Eastern and Southern Africa: A review of practices and policies. ICRAF Working Paper no. 18. Nairobi, Kenya. World Agro forestry Centre.

Knowler D, B Bradshaw B (2007). Farmers' Adoption of Conservation Agriculture: A Review and Synthesis of Recent Research, Food Policy, 32, 25-48.

Lugari District Development Plan (2008-2012). Nairobi. Government Printers.

Maitima JM, Mugatha SM, Reid RS, Gachimbi LN, Majule A, Lyaruu H, Pomery D, Mathai S, Mugisha S (2009). The Linkages between land use change, land degradation and biodiversity across East Africa. Journal of Environmental Science and Technology, 3 (21), 310-325

Matano AS, Kanangire CK, Anyona DN, Abuom PO, Gelder FB, Dida GO, Owuor PO, Ofulla AVO (2015). Effects of Land Use Change on Land Degradation Reflected by Soil Properties along Mara River, Kenya and Tanzania, Open J Soil Sci, 5, 20-38

McDonagh J, Stocking M, Lu Y (2006). Global Impacts of Land Degradation. Overseas Development Group, University of East Anglia, Norwich, United Kingdom

Nkonya E, Gerber N, von Braun J, de Pinto A (2011). Economics of Land Degradation: The Cost of Action versus Inaction, IFPRI, Washington, DC, USA

Oluwole FA, Sikhalazo D (2008). Land degradation evaluation in a game reserve in Eastern Cape of South Africa: soil properties and vegetation cover. Scientific Research and Essay, 3, 111- 119

Scherr SJ, Sthapit S (2009). Mitigating Climate Change through Food and Land Use. World Watch Institute, Washington DC, USA

Wafuke S (2012). Adoption of Agroforestry Technologies among Small Scale Farmers in Nzoia Location, Lugari District, Kenya. Unpublished Thesis. Egerton University 